\title{
Real-World Scenario Improvements in Serum Phosphorus Levels and Pill Burden in Peritoneal Dialysis Patients Treated with Sucroferric Oxyhydroxide
}

\author{
Kamyar Kalantar-Zadeh ${ }^{a}$ Vidhya Parameswaran $^{\mathrm{b}}$ Linda H. Ficociello ${ }^{\mathrm{b}}$ \\ Ludmila Anderson $^{\mathrm{b}}$ Norma J. Ofsthun ${ }^{\mathrm{b}}$ Christopher Kwoh ${ }^{c, d}$ Claudy Mullon ${ }^{\mathrm{b}}$ \\ Robert J. Kossmann ${ }^{b}$ Daniel W. Coyne ${ }^{e}$ \\ a University of California Irvine, School of Medicine, Irvine, CA, USA; ${ }^{b}$ Fresenius Medical Care North America,

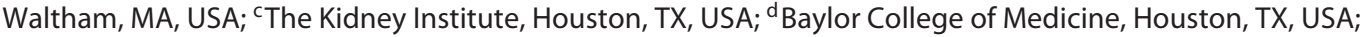 \\ eWashington University School of Medicine, St. Louis, MO, USA
}

\section{Keywords}

Chronic kidney disease-mineral bone disorders · Phosphate binders · Peritoneal Dialysis · Phosphorus

\begin{abstract}
Background: A database analysis was conducted to assess the effectiveness of sucroferric oxyhydroxide (SO) on lowering serum phosphorus and phosphate binder $(\mathrm{PB})$ pill burden among adult peritoneal dialysis (PD) patients prescribed SO as part of routine care. Methods: Adult PD patients ( $n=$ 258) prescribed SO through a renal pharmacy service were analyzed. Baseline was 3 months before SO prescription. SOtreated follow-up was for 6 months or until either a new PB was prescribed, SO was not refilled, PD modality changed, or patient was discharged. In-range serum phosphorus was defined as $\leq 5.5 \mathrm{mg} / \mathrm{dL}$. Results: At baseline, mean serum phosphorus was $6.59 \mathrm{mg} / \mathrm{dL}$ with 10 prescribed PB pills/day. The proportion of patients achieving in-range serum phosphorus increased by $72 \%$ from baseline to month 6 . Prescribed PB pills/day decreased by $57 \%$ (10 at baseline to 4.3 at SO follow-up, $p<0.0001)$. The mean length of $\mathrm{SO}$ follow-up was 5.1 months; SO follow-up ended for 38,27 , and 50 patients
\end{abstract}

\begin{tabular}{ll}
\hline KARGER & $\begin{array}{l}\text { (c) } 2018 \text { The Author(s) } \\
\text { Published by S. Karger AG, Basel }\end{array}$ \\
E-Mail karger@karger.com & $\begin{array}{l}\text { This article is licensed under the Creative Commons Attribution- } \\
\text { NonCommercial-NoDerivatives 4.0 International License (CC BY- } \\
\text { NC-ND) (http://www.karger.com/Services/OpenAccessLicense). } \\
\text { Usage and distribution for commercial purposes as well as any dis- } \\
\text { tribution of modified material requires written permission. }\end{array}$
\end{tabular}

at months 4, 5, and 6, respectively, due to no further PB fills, and for 10,11 , and 4 patients at months 4,5 , and 6 , respectively, due to another PB prescribed. In patients with baseline serum phosphorus $>5.5 \mathrm{mg} / \mathrm{dL}$ who achieved in-range serum phosphorus during SO follow-up for $\geq 1$ quarter, a notable improvement in serum phosphorus (6.54 to $5.10 \mathrm{mg} /$ $\mathrm{dL}, p<0.0001$ ) was observed, and there was a $53 \%$ reduction in PB pill burden (9.9 to 4.7, $p<0.0001$ ). Conclusion: Among PD patients prescribed SO as part of routine care, improvements in serum phosphorus control and $>50 \%$ reduction in $\mathrm{PB}$ pills/day were observed. (c) 2018 The Author(s)

Published by S. Karger AG, Basel

\section{Background}

Peritoneal dialysis (PD) represents a safe and cost-effective treatment modality for patients with end-stage renal disease (ESRD) [1-4]. In the United States, by the end of 2014, 6.9\% of prevalent ESRD cases were treated with PD [5]. Disorders of phosphorus metabolism among ESRD patients are common, with serum phosphorus levels in PD patients generally lower than in hemodialysis

Kamyar Kalantar-Zadeh, MD, PhD

University of California Irvine School of Medicine

1001 Health Sciences Road

Irvine, CA 92697-3950 (USA)

E-Mail kkz@uci.edu 
(HD) patients [6-8], though treatment with oral phosphate binders (PBs) are usually indicated [9]. Favorable properties of PBs would include low pill burden, low cost, minimal systemic absorption, and minimal side effects [6, 10]. Potential risks include toxicity, gastrointestinal side effects, and contribution to hypercalcemia [11-13]. Adherence to PB therapy is essential for phosphorus control, and low pill burden may be a key factor in adherence [1416]. PD patients are prescribed, on average, 16-19 pills/ day $[17,18]$ and half are PBs [18].

Sucroferric oxyhydroxide (SO) is an iron-based, chewable PB with a low pill burden indicated for treatment of hyperphosphatemia in patients with chronic kidney disease on dialysis. Coyne et al. [19] reported significantly decreased pill burden and improved serum phosphorus levels among HD patients prescribed SO as part of routine clinical care. Floege et al. [20] reported results from a phase 3 randomized controlled trial and found $\mathrm{SO}$ to be non-inferior to sevelamer carbonate for the control of serum phosphorus in $\mathrm{PD}$ patients, with a lower pill burden. The objective of this retrospective database analysis was to assess the effectiveness of SO on lowering serum phosphorus levels and $\mathrm{PB}$ pill burden among adult $\mathrm{PD}$ patients prescribed $\mathrm{SO}$ as part of routine clinical care.

\section{Methods}

SO (Velphoro ${ }^{\circledR}$, Fresenius Medical Care Renal Therapies Group, Waltham, MA, USA) is usually prescribed with a starting dose of 3 pills/day, administered as 1 tablet with each meal and titrated in increments or decrements of 1 tablet per day.

Adult (age $>18$ years) PD patients who were prescribed SO as part of routine clinical care at Fresenius Kidney Care (FKC) facilities and who received their first SO prescription through FreseniusRx (a specialty renal pharmacy service) between April 1, 2014 and October 30, 2015, were included in this retrospective analysis. Patients were required to have $\geq 3$ months of SO prescription fills recorded, uninterrupted by another $\mathrm{PB}$. De-identified demographic and clinical data were retrieved from the FKC data warehouse; $\mathrm{PB}$ prescription information originated from the Fresenius$\mathrm{Rx}$ database. To supplement baseline PB information, we used PB orders from the FKC Electronic Health Record (EHR). However, we cannot assume that the orders recorded in this database are as precise or accurate as documented prescription fills; thus, only documented prescriptions were used for calculations of PB pills per day. Treatment periods for assessment and comparison were defined as baseline (BL; 3 months before SO prescription), and SOtreated follow-up (SO; up to 6 months of SO prescription). SOtreated follow-up was 6 months or until either a new PB was prescribed, SO was not refilled, PD modality changed, or patient was discharged from FKC.

Basic demographic and treatment characteristics were evaluated at baseline. Clinical parameters included PB pills/day, min- eral and bone disease markers (serum phosphorus, serum calcium, intact parathyroid hormone [iPTH]), nutritional and clearance parameters (weight, serum albumin, normalized protein catabolic rate $[\mathrm{nPCR}]$, serum creatinine, total $\mathrm{Kt} / \mathrm{V}[\mathrm{PD}$ + residual renal function], $\mathrm{PD} \mathrm{Kt} / \mathrm{V}$, and residual urea clearance $\left.\left[\mathrm{K}_{\mathrm{ru}}\right]\right)$; and anemia and iron indices (ferritin, transferrin saturation [TSAT], hemoglobin, and iron). Laboratory tests were measured monthly, except for ferritin and $\mathrm{PTH}$, which were measured quarterly. Calcium was albumin-corrected using the Payne's formula [21]. Serum albumin and nPCR were each divided by serum phosphorus to calculate phosphorus-attuned albumin and nPCR. Baseline $\mathrm{K}_{\mathrm{ru}}$ was categorized into 3 groups: unavailable; $\leq 3 \mathrm{~mL} / \mathrm{min} / 1.73 \mathrm{~m}^{2}$; and $>3.0 \mathrm{~mL} /$ $\min / 1.73 \mathrm{~m}^{2}$. Spectra Laboratories (Rockleigh, NJ, USA) performed all laboratory tests.

Repeated-measures data were analyzed using linear mixed-effects regression. Mean clinical measures were summarized using least-squared means and compared between baseline and SO follow-up. In-range serum phosphorus was defined as mean serum phosphorus $\leq 5.5 \mathrm{mg} / \mathrm{dL}$. To determine the impact of intermittent HD on changes in serum phosphorus, an analysis was conducted where all serum phosphorus levels were deleted for months when patients had intermittent $\operatorname{HD}(n=23)$. A sub-group analysis was conducted for all patients achieving serum phosphorus $\leq 5.5 \mathrm{mg}$ / $\mathrm{dL}$ during at least 1 quarter of SO follow-up and a subset of these patients with baseline serum phosphorus $>5.5 \mathrm{mg} / \mathrm{dL}$. Sub-analysis by $\mathrm{K}_{\mathrm{ru}}$ group was conducted to assess effect measure modification by residual renal function. For this sub-analysis, missing baseline $\mathrm{K}_{\mathrm{ru}}$ were imputed for 33 patients with follow-up $\mathrm{K}_{\mathrm{ru}}$ measured. Serum phosphorus levels were compared for subgroups that did and did not complete 6 months of SO treatment. $P$ values $<0.05$ were considered statistically significant. All analyses were conducted using SAS version 9.4 (SAS Institute Inc., Cary, NC, USA). This database analysis was approved by the New England Institutional Review Board.

\section{Results}

\section{Analysis of Study Cohort $(\mathrm{n}=258)$}

In total, 258 patients met the requirements for analysis. Patients were, on average, $50.6 \pm 13.9$ years old, with a mean dialysis vintage of $29.3 \pm 27.6$ months (Table 1 ). The majority of patients (76\%) received continuous cycling PD (CCPD), 13.2\% received continuous ambulatory $\mathrm{PD}$ (CAPD), and the remaining patients (10.8\%) switched from CAPD to CCPD during baseline. On average, patients were prescribed $4.9 \pm 1$ exchanges per day and $6.8 \pm 0.6$ days per week. The mean length of SO follow-up was 5.1 months; 151 patients did not complete all 6 months of SO monotherapy. SO follow-up ended for 38, 27 , and 50 patients at months 4,5 , and 6 , respectively, due to no further PB fills, and for 10,11 , and 4 patients at months 4, 5, and 6, respectively, due to another PB prescribed. The other 11 patients who did not complete the 6 months were discharged from the clinic or switched to 
HD. (See monthly patient disposition in online suppl. Table S1; for all online suppl. material, see www.karger.com/ doi/10.1159/000487856). The majority of patients with PB fills from FreseniusRx at baseline $(n=92)$ were prescribed sevelamer $(63.0 \%)$, followed by calcium acetate (20.7\%), more than 1 PB (10.9\%) and lanthanum carbonate $(5.4 \%)$. The remainder of patients $(n=166)$ had no recorded baseline PB fills in the FreseniusRx database. Among the 166 patients who did not receive a Fresenius$\mathrm{Rx}$ PB fill during baseline, 110 patients had $\mathrm{PB}$ prescriptions available through the FKC EHR database. Figure 1 shows that the distribution of $\mathrm{PB}$ type was similar at baseline for patients with and without $\mathrm{PB}$ prescriptions through FreseniusRx.

Mean changes between baseline and SO follow-up are compared in Table 2. A significant improvement was observed in mean serum phosphorus $(6.59 \mathrm{mg} / \mathrm{dL}$ at BL to $6.26 \mathrm{mg} / \mathrm{dL}$ at SO, $p<0.0001)$. Prescribed PB pills/day decreased by $57 \%$ from 10 pills/day at baseline to 4.3 pills/ day at SO follow-up $(p<0.0001)$. There was a slight decrease in corrected calcium ( 9.36 to $9.31 \mathrm{mg} / \mathrm{dL}, p=0.018$ ) and a slight increase in intact PTH from 468 to $497 \mathrm{pg} /$ $\mathrm{mL}(p=0.03)$. There were no changes observed in unadjusted nPCR $(1.0 \mathrm{~g} / \mathrm{kg} /$ day at BL and SO, $p=0.9)$ and weight ( 86.8 to $86.9 \mathrm{~kg}, p=0.8$ ), but a slight decrease was observed in unadjusted serum albumin from 3.70 to 3.62 $\mathrm{g} / \mathrm{dL}(p<0.0001)$. When adjusted for serum phosphorus, increases were observed in phosphorus-attuned albumin from $0.6 \times 10^{3}$ at BL to $0.63 \times 10^{3}$ at SO follow-up $(p<$ $0.0001)$, and phosphorus-attuned nPCR $\left(0.17 \times 10^{3}\right.$ to $0.18 \times 10^{3} \mathrm{dL} / \mathrm{kg} /$ day, $\left.p=0.04\right)$. Although there was a slight decrease in $\mathrm{K}_{\mathrm{ru}}\left(2.85\right.$ to $2.47 \mathrm{~mL} / \mathrm{min} / 1.73 \mathrm{~m}^{2}, p=$ 0.008 ) and increase in serum creatinine ( 12.0 to $12.2 \mathrm{mg} /$ $\mathrm{dL}, p=0.001)$, there were no changes in total Kt/V (2.1 at $\mathrm{BL}$ and $\mathrm{SO}, p=0.7)$ and a numeric increase in $\mathrm{PD} \mathrm{Kt} / \mathrm{V}$ (1.65 to $1.70, p=0.5$ ).

As a sensitivity analysis, several subgroup analyses on serum phosphorus changes were conducted. There were 21 patients who received intermittent HD during the study periods. Changes in serum phosphorus levels after removing these measurements showed a similar improvement in serum phosphorus (6.60 to $6.25 \mathrm{mg} / \mathrm{dL}, p<$ $0.0001)$. Patients who completed the full 6 months of SO follow-up $(n=107)$ had serum phosphorus reduced from $6.56 \mathrm{mg} / \mathrm{dL}$ at BL to $6.16 \mathrm{mg} / \mathrm{dL}$ at $\mathrm{SO}$ follow-up $(p<$ $0.0001)$. PB pill burden reduced from 9.9 to 4.3 pills/day $(p<0.0001)$ for the patients prescribed PB at baseline (92 patients out of the 107). Patients with PB prescriptions recorded through FreseniusRx at baseline and who completed the 6 -month follow-up $(n=30)$ had a mean serum
Table 1. Baseline characteristics at SO therapy initiation

\begin{tabular}{|c|c|}
\hline Baseline characteristic & $\begin{array}{l}\text { Study cohort } \\
(n=258)\end{array}$ \\
\hline Age, years & $50.6 \pm 13.9$ \\
\hline Dialysis vintage, months & $29.3 \pm 27.5$ \\
\hline $\mathrm{BMI}, \mathrm{kg} / \mathrm{m}^{2}$ & $30.4 \pm 8$ \\
\hline Gender, male, $n(\%)$ & $143(55.4)$ \\
\hline \multicolumn{2}{|l|}{ Race, $n(\%)$} \\
\hline White & $160(62.0)$ \\
\hline African American & $64(24.8)$ \\
\hline Other & $34(13.2)$ \\
\hline Diabetes, $n(\%)$ & $121(46.9)$ \\
\hline \multicolumn{2}{|l|}{ Primary cause of ESRD, $n(\%)$} \\
\hline Diabetes mellitus & $90(34.9)$ \\
\hline Hypertension & $69(26.7)$ \\
\hline Glomerulonephritis & $47(18.2)$ \\
\hline Polycystic kidney disease & $10(3.9)$ \\
\hline Other & $34(13.2)$ \\
\hline Unknown & $8(3.1)$ \\
\hline \multicolumn{2}{|l|}{ Baseline PB dispensed through FreseniusRx } \\
\hline No PB recorded, $n(\%)$ & $166(64.3)$ \\
\hline $\mathrm{PB}$ recorded in the FKC EHR database, $n(\%)$ & $110(66.3)$ \\
\hline $\mathrm{PB}$ recorded, $n(\%)$ & $92(35.7)$ \\
\hline Calcium acetate, $n(\%)$ & $19(20.7)$ \\
\hline Lanthanum carbonate, $n(\%)$ & $5(5.4)$ \\
\hline Sevelamer, $n(\%)$ & $58(63.0)$ \\
\hline$>1 \mathrm{~PB}$ recorded, $n(\%)$ & $10(10.8)$ \\
\hline \multicolumn{2}{|l|}{ PD modality, $n(\%)$} \\
\hline Manual (CAPD) & $34(13.2)$ \\
\hline Automated (CCPD) & $196(76)$ \\
\hline Switched (CAPD to CCPD) & $28(10.8)$ \\
\hline \multicolumn{2}{|l|}{ Clinical parameters } \\
\hline Serum phosphorus, mg/dL & $6.5 \pm 1.4$ \\
\hline Albumin-corrected calcium, mg/dL & $9.4 \pm 0.7$ \\
\hline Intact PTH, pg/mL & $459 \pm 317$ \\
\hline Serum albumin, g/dL & $3.7 \pm 0.4$ \\
\hline $\mathrm{K}_{\mathrm{ru}}, \mathrm{mL} / \mathrm{min} / 1.73 \mathrm{~m}^{2}$ & $2.72 \pm 2.45$ \\
\hline $\mathrm{PD} \mathrm{Kt} / \mathrm{V}$ & $1.7 \pm 0.4$ \\
\hline Total Kt/V & $2.2 \pm 0.5$ \\
\hline
\end{tabular}

Values are expressed as mean $\pm \mathrm{SD}$, or $n(\%)$.

BMI, body mass index $\left(\mathrm{kg} / \mathrm{m}^{2}\right)$; CAPD, continuous ambulatory $\mathrm{PD}$; CCPD, continuous cycling $\mathrm{PD} ; \mathrm{K}_{\mathrm{ru}}$, residual urea clearance; FKC EHR, Fresenius Kidney Care Electronic Health Records; PB, phosphate binder; $\mathrm{PD}$, peritoneal dialysis; $\mathrm{PTH}$, parathyroid hormone; ESRD, end-stage renal disease.

phosphorus decrease from $6.33 \mathrm{mg} / \mathrm{dL}$ at baseline month -1 (month before switch to SO) to $5.37 \mathrm{mg} / \mathrm{dL}$ at month 6 of SO follow-up $(p<0.001)$ and percentage of patients achieving in-range serum phosphorus levels increased from $11(29.7 \%)$ patients at baseline month -1 to 18 (48.6\%) patients at SO follow-up month 6. Patients with $\mathrm{PB}$ prescriptions recorded through FreseniusRx or FKC 
Fig. 1. Baseline $\mathrm{PB}$ prescriptions prior to SO initiation. * Combination of sevelamer, calcium acetate, and/or lanthanum carbonate. FKC EHR, Fresenius Kidney Care Electronic Heath Record database; PB, phosphate binder.

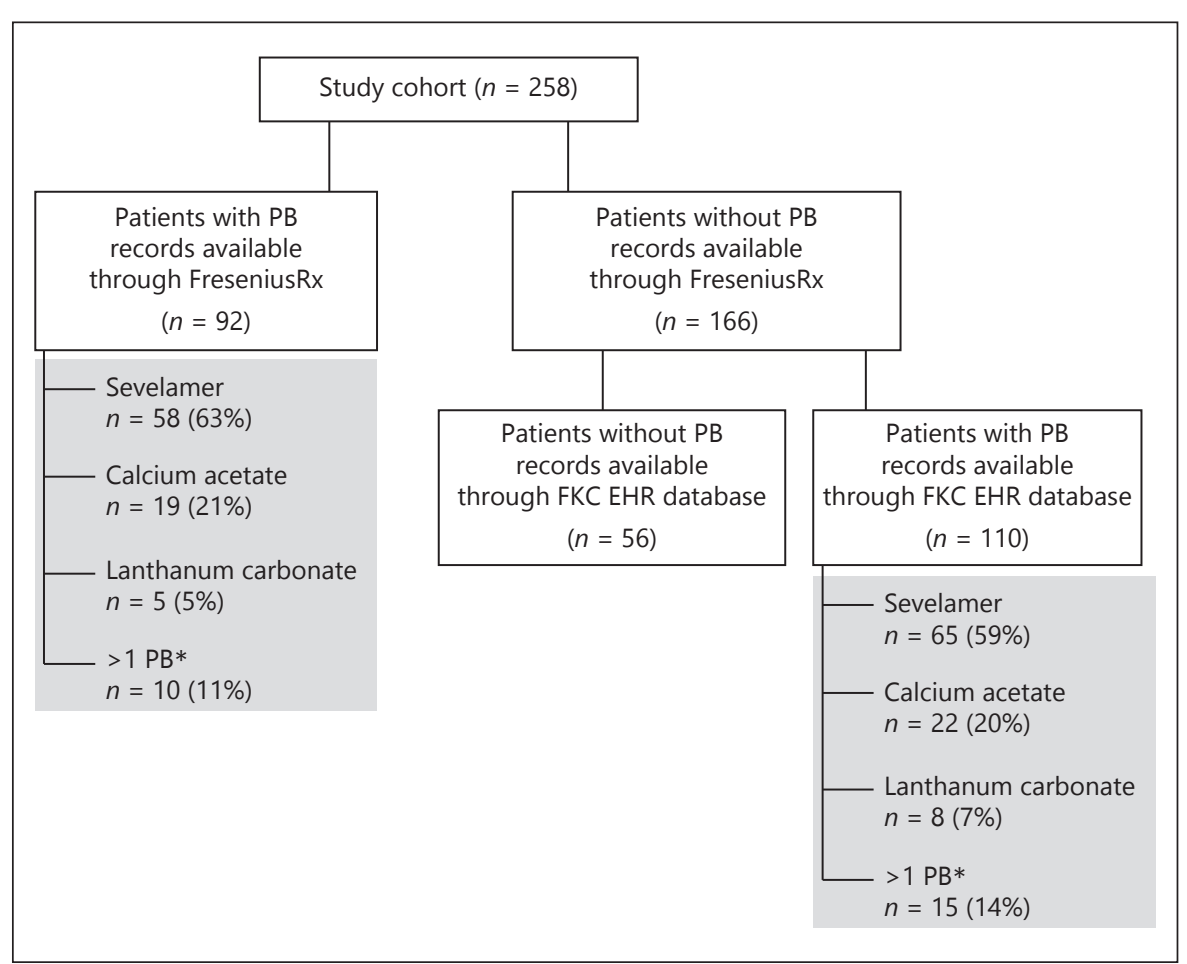

EHR database at baseline and who completed the 6-month follow-up $(n=84)$ had a mean serum phosphorus decrease from $6.90 \mathrm{mg} / \mathrm{dL}$ at baseline month -1 to $5.94 \mathrm{mg} /$ $\mathrm{dL}$ at SO follow-up month $6(p<0.0001)$ and the percentage of patients achieving in-range serum phosphorus levels increased from 21 (25\%) patients at baseline month -1 to $34(40.5 \%)$ at SO follow-up month 6 . An additional analysis of patients who did not complete the full 6 months of SO follow-up was conducted using all serum phosphorus measurements available, regardless of the end of SO monotherapy prescription, and they had a mean serum phosphorus of 6.62 at $\mathrm{BL}$ and $6.34 \mathrm{mg} / \mathrm{dL}$ at follow-up $(p<0.001)$.

At baseline, 127 (49.2\%) patients received IV iron therapy and $195(75.6 \%)$ patients received erythropoietinstimulating agent therapy. At SO follow-up, 132 (51.1\%) patients received IV iron therapy (iron sucrose) and 200 (77.5\%) patients received erythropoietin-stimulating agent therapy. Mean iron sucrose dose was minimally changed from $202 \mathrm{mg} / \mathrm{month}$ at BL to $204 \mathrm{mg} / \mathrm{month}$ at SO follow-up $(p=0.6)$. Similarly, mean epoetin alfa dose was minimally changed from 11,805 to 11,667 units/ month $(p=0.5)$ among patients treated exclusively with epoetin alfa (83\%). Among patients who received IV iron therapy $(n=165)$, significant increases in ferritin (748 to $940 \mathrm{ng} / \mathrm{mL}, p<0.0001$ ), TSAT ( 34.0 to $38.4 \%, p<0.0001$ ) and hemoglobin (10.6 to $10.7 \mathrm{~g} / \mathrm{dL}, p=0.08$ ) were observed from baseline to SO follow-up. Among patients who did not receive any IV iron therapy $(n=93)$, serum ferritin increased from 801 to $876 \mathrm{ng} / \mathrm{mL}(p=0.02)$, hemoglobin increased from 11.2 to $11.3 \mathrm{~g} / \mathrm{dL}(p=0.03)$ and TSAT was unchanged $(38.5 \%, p=0.9)$.

The percentage of patients achieving in-range serum phosphorus $(\leq 5.5 \mathrm{mg} / \mathrm{dL}$ ) increased from baseline to $\mathrm{SO}$ follow-up (Fig. 2). At baseline 30.1, 25.4, and 25.8\% of patients were in-range for serum phosphorus at months $-3,-2$, and -1 respectively. During $\mathrm{SO}$ follow-up, the percent of patients who were in-range for serum phosphorus increased to $35.3,37.5,41.8,36.8,38.9$, and $44.4 \%$ at months 1-6, respectively. Comparing BL month -1 to SO follow-up month 6 , there was a $72 \%$ increase in patients achieving in-range serum phosphorus along with $>50 \%$ reduction in $\mathrm{PB}$ pills/day.

\section{Analysis of Patients with In-Range Serum Phosphorus \\ Recorded During SO Follow-Up}

Patients $(n=110)$ who achieved in-range serum phosphorus during $\geq 1$ quarter of SO follow-up were analyzed to determine the associated effects of being in-range on other mineral bone disease and nutrition markers (Table $3)$. Among these patients, 75 patients $(68 \%)$ had a recorded $\mathrm{PB}$ at baseline (67\% sevelamer, $27 \%$ calcium acetate, 
Table 2. Comparison of clinical parameters between baseline and SO therapy (258 PD patients)

\begin{tabular}{|c|c|c|c|}
\hline Parameter & Baseline & SO follow-up & $p$ value \\
\hline PB pills/day* & $10.0(0.2)$ & $4.3(0.2)$ & $<0.0001$ \\
\hline \multicolumn{4}{|l|}{ Mineral and bone disease markers } \\
\hline Serum phosphorus, mg/dL & $6.59(0.09)$ & $6.26(0.09)$ & $<0.0001$ \\
\hline Albumin-corrected calcium, mg/dL & $9.36(0.04)$ & $9.31(0.04)$ & 0.018 \\
\hline Intact PTH, pg/mL & $468(23)$ & $497(22)$ & 0.032 \\
\hline \multicolumn{4}{|l|}{ Nutritional and clearance parameters } \\
\hline Weight, kg & $86.8(1.5)$ & $86.9(1.5)$ & 0.8 \\
\hline Serum albumin, g/dL & $3.70(0.02)$ & $3.62(0.02)$ & $<0.0001$ \\
\hline Phosphorus-attuned albumin, $\times 10^{3}$ & $0.6(0.01)$ & $0.63(0.01)$ & $<0.0001$ \\
\hline $\mathrm{nPCR}, \mathrm{g} / \mathrm{kg} /$ day & $1.0(0.03)$ & $1.0(0.02)$ & 0.9 \\
\hline Phosphorus-attuned nPCR, $\times 10^{3} \mathrm{dL} / \mathrm{kg} /$ day & $0.17(0.005)$ & $0.18(0.004)$ & 0.044 \\
\hline Serum creatinine, $\mathrm{mg} / \mathrm{dL}$ & $12.0(0.3)$ & $12.2(0.3)$ & 0.001 \\
\hline $\mathrm{K}_{\mathrm{ru}}, \mathrm{mL} / \mathrm{min} / 1.73 \mathrm{~m}^{2}$ & $2.85(0.20)$ & $2.47(0.19)$ & 0.008 \\
\hline $\mathrm{PD} \mathrm{Kt} / \mathrm{V}$ & $1.65(0.05)$ & $1.70(0.04)$ & 0.5 \\
\hline Total Kt/V & $2.1(0.06)$ & $2.1(0.05)$ & 0.7 \\
\hline \multicolumn{4}{|l|}{ Anemia and iron indices } \\
\hline \multicolumn{4}{|l|}{ Patients not receiving IV iron therapy $(n=93)$} \\
\hline Ferritin, ng/mL & $801(66)$ & $876(65)$ & 0.018 \\
\hline Transferrin saturation, $n(\%)$ & $38.5(1.4)$ & $38.5(1.3)$ & 0.9 \\
\hline Hemoglobin, g/dL & $11.2(0.2)$ & $11.3(0.2)$ & 0.039 \\
\hline Iron, $\mathrm{mcg} / \mathrm{dL}$ & $98.1(3.5)$ & $93.2(3.2)$ & 0.077 \\
\hline \multicolumn{4}{|l|}{ Patients receiving IV iron therapy $(n=165)$} \\
\hline Ferritin, ng/mL & $748(36)$ & $940(34)$ & $<0.0001$ \\
\hline Transferrin saturation, $n(\%)$ & $34.0(0.9)$ & $38.4(0.8)$ & $<0.0001$ \\
\hline Hemoglobin, g/dL & $10.6(0.1)$ & $10.7(0.1)$ & 0.078 \\
\hline Iron, $\mathrm{mcg} / \mathrm{dL}$ & $85.8(2.4)$ & $92.3(2.1)$ & 0.005 \\
\hline
\end{tabular}

Values are expressed as least-squared means (SE), $p$ values compare least-squared means between treatment periods.

* Pill burden at baseline was calculated only for patients who received PB prescriptions through FreseniusRx $(n=92)$. Follow-up PB pill burden for patients with no baseline binder available through FreseniusRx $(n=166)$ was found to be $4.3 \mathrm{SO}$ pills/day.

$\mathrm{K}_{\mathrm{ru}}$, residual urea clearance; $\mathrm{nPCR}$, normalized protein catabolic rate; $\mathrm{PD}$, peritoneal dialysis; $\mathrm{PTH}$, parathyroid hormone; SO, sucroferric oxyhydroxide; $\mathrm{PB}$, phosphate binder.

4\% lanthanum carbonate, and 3\% PB combination therapy), and 35 patients (32\%) did not have a recorded $\mathrm{PB}$ at baseline (for prescriptions by month, see online suppl. Table S2). Comparing baseline and SO follow-up, a $>50 \%$ reduction in PB pill burden (9.3 to 4.4 pills/day, $p<0.0001$ ) and an improvement in serum phosphorus (5.81 to 4.97 $\mathrm{mg} / \mathrm{dL}, p<0.0001)$ were observed. Intact PTH was unchanged (406 to $425 \mathrm{pg} / \mathrm{mL}, p=0.4$ ). There was a slight decrease in corrected calcium $(9.43$ to $9.36 \mathrm{mg} / \mathrm{dL}, p=$ 0.08 ) and serum albumin ( 3.70 to $3.64 \mathrm{~g} / \mathrm{dL}, p<0.001$ ), and no changes observed in nPCR $(1.0 \mathrm{~g} / \mathrm{kg} /$ day, $p=0.2)$. Comparing baseline and SO follow-up, there were significant improvements in phosphorus-attuned albumin $\left(0.68 \times 10^{3}\right.$ to $\left.0.77 \times 10^{3}, p<0.0001\right)$ and phosphorus-attuned nPCR $\left(0.18 \times 10^{3}\right.$ to $0.21 \times 10^{3} \mathrm{dL} / \mathrm{kg} /$ day, $\left.p<0.001\right)$.
Among patients who achieved in-range serum phosphorus during SO follow-up, 97 patients did not change PD prescription modality (86\% CCPD, 14\% CAPD, mean serum phosphorus $5.69 \mathrm{mg} / \mathrm{dL}$ at baseline and 4.94 $\mathrm{mg} / \mathrm{dL}$ at $\mathrm{SO}$ follow-up, $p<0.0001)$, and 13 patients were prescribed a switch between both PD modalities (mean serum phosphorus was $6.42 \mathrm{mg} / \mathrm{dL}$ at baseline and 4.92 $\mathrm{mg} / \mathrm{dL}$ at SO follow-up, $p<0.001)$. Fifty-nine patients did not change the prescribed number of PD exchanges/ day (mean number of PD exchanges $=4.7 /$ day, mean serum phosphorus $5.57 \mathrm{mg} / \mathrm{dL}$ at baseline and $5.02 \mathrm{mg} / \mathrm{dL}$ at SO follow-up, $p<0.0001)$. Fifty-one patients had an increase in prescribed number of PD exchanges/day (mean $=4.8 /$ day at baseline and 5.2/day at follow-up) and had a mean serum phosphorus of $6.03 \mathrm{mg} / \mathrm{dL}$ at 


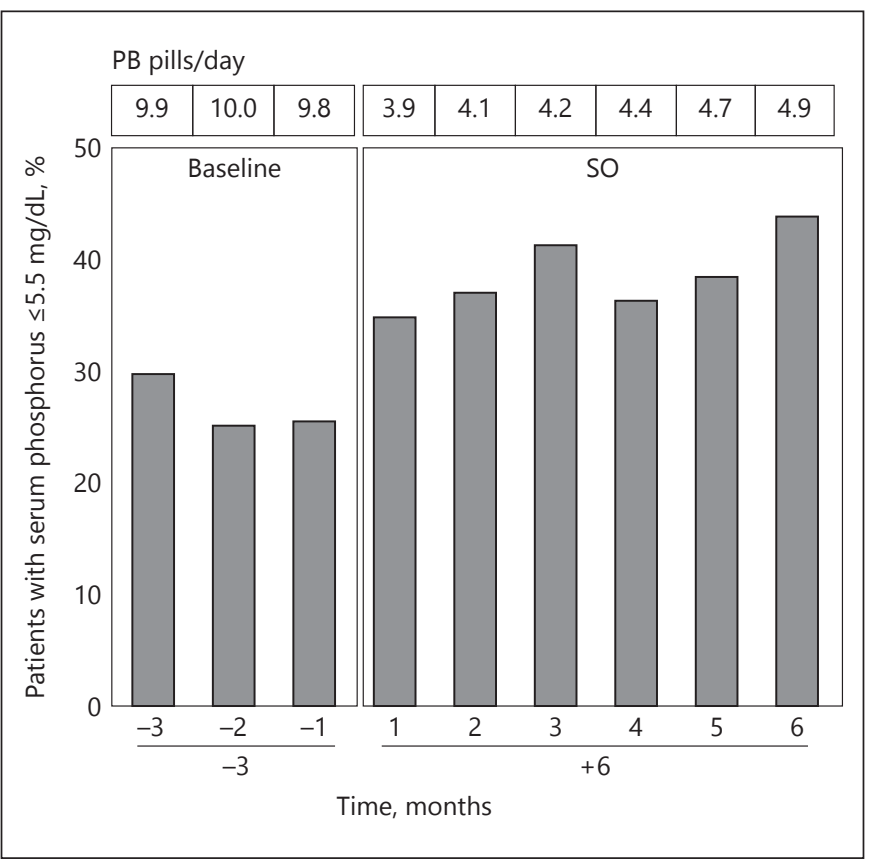

Fig. 2. Percent of patients with monthly serum phosphorus $\leq 5.5$ $\mathrm{mg} / \mathrm{dL}$ at baseline and $\mathrm{SO}$ follow-up. $\mathrm{PB}$ pills/day for patients with in-range serum phosphorus decreased from $(9.7,8.8$, and 9.0) at baseline to $(3.9,4.4,4.2,4.4,4.5$, and 4.8$)$ at $\mathrm{SO}$ follow-up. SO, sucroferric oxyhydroxide; $\mathrm{PB}$, phosphate binder.

baseline and $4.83 \mathrm{mg} / \mathrm{dL}$ at SO follow-up $(p<0.0001)$. Eighty-three patients received 7 days/week of PD treatment throughout baseline and follow-up (mean serum phosphorus $=5.81 \mathrm{mg} / \mathrm{dL}$ at baseline and $4.91 \mathrm{mg} / \mathrm{dL}$ at SO follow-up, $p<0.0001$ ), and 27 patients had an increase in prescribed number of days of PD treatment (5.6 PD treatment days/week at baseline and 6.8 PD treatment days/week at $\mathrm{SO}$ follow-up) and serum phosphorus decrease of $0.7 \mathrm{mg} / \mathrm{dL}(5.69 \mathrm{mg} / \mathrm{dL}$ at baseline to 4.98 $\mathrm{mg} / \mathrm{dL}$ at SO follow-up, $p=0.008$ ). A subset of the patients $(n=63)$ who achieved in-range serum phosphorus during SO follow-up had serum phosphorus levels $>5.5$ $\mathrm{mg} / \mathrm{dL}$ during baseline (Table 3). Comparing baseline and SO follow-up, a notable improvement in serum phosphorus $(6.54$ to $5.10 \mathrm{mg} / \mathrm{dL}, p<0.0001)$ was observed along with a $53 \%$ reduction in $\mathrm{PB}$ pill burden (9.9 to 4.7 pills/day, $p<0.0001)$. There were nonsignificant changes in intact PTH (430 to $391 \mathrm{pg} / \mathrm{mL}, p=0.09$ ), corrected calcium ( 9.31 to $9.36 \mathrm{mg} / \mathrm{dL}, p=0.3$ ), and total $\mathrm{Kt} / \mathrm{V}(2.0$ to $2.2, p=0.3)$. Although a slight decrease in serum albumin (3.71 to $3.63 \mathrm{~g} / \mathrm{dL}, p=0.001$ ) was observed, phosphorus-attuned albumin $\left(0.59 \times 10^{3}\right.$ to $\left.0.75 \times 10^{3}, p<0.0001\right)$ and phosphorus-attuned nPCR $\left(0.17 \times 10^{3}\right.$ to $0.21 \times 10^{3} \mathrm{dL} / \mathrm{kg} /$ day, $\left.p<0.0001\right)$ increased.
Assessing the Impact of Residual Renal Function on PB Pill Burden and Serum Phosphorus Levels

In Table 4, patients are stratified by their baseline $\mathrm{K}_{\mathrm{ru}}$. The $\mathrm{K}_{\mathrm{ru}}>3$ group had more patients with baseline and $\mathrm{SO}$ follow-up serum phosphorus levels $\leq 5.5 \mathrm{mg} / \mathrm{dL}$ ( 40.2 and $52.8 \%$, respectively) when compared to patients for whom $\mathrm{K}_{\mathrm{ru}}$ was not measured (15.6 and 31.3\%) and patients with $\mathrm{K}_{\mathrm{ru}} \leq 3$ (14.8 and 25.4\%). Patients with $\mathrm{K}_{\mathrm{ru}}>3$ also had lower baseline and $\mathrm{SO}$ follow-up $\mathrm{PB}$ pills/day (6.7 and 3.7 pills, respectively) when compared to patients for whom $\mathrm{K}_{\mathrm{ru}}$ was not measured (10.7 and 4.4 pills) and patients with $\mathrm{K}_{\mathrm{ru}} \leq 3$ (10.6 and 4.4 pills).

\section{Discussion}

The current retrospective analysis included patients treated under routine care and the analysis had no impact on the prescription or treatment of the patients. The patients did not go through a wash-out period and the current analysis relied on physician judgment and preference in $\mathrm{PB}$ choice. Compared to a representative national sample of dialysis patients, with $34 \%$ of patients with serum phosphorus $>5.5 \mathrm{mg} / \mathrm{dL}$ [22], the patients in our analysis could be considered difficult to treat, as $74 \%$ had serum phosphorus $>5.5 \mathrm{mg} / \mathrm{dL}$. However, a $72 \%$ increase of patients in-range for serum phosphorus $(\leq 5.5 \mathrm{mg} / \mathrm{dL})$ was achieved with $\mathrm{SO}$, with an absolute level of $44.4 \%$ of patients in-range at 6 months and a 57\% reduction in PB pills/day.

Nonadherence to prescribed $\mathrm{PB}$ regimen has been reported in $62 \%$ of dialysis patients [18]. $\mathrm{PB}$ pill burden is a cited determinant of PB adherence [6]. Thus, the observed average pill burden decreased from 10 to 5 pills/ day is favorable. The increase in adherence to PB therapy may be a factor in the improvements in serum phosphorus control in patients prescribed SO.

Floege et al. [20], as a sub-analysis of a phase III study, focused on PD patients over 1 year of follow-up and found $\mathrm{SO}$ effective for the lowering of serum phosphorus levels. Although patients in the SO arm had higher baseline serum phosphorus levels when compared to the sevelamer arm $(7.5 \mathrm{mg} / \mathrm{dL}$ compared to $6.7 \mathrm{mg} / \mathrm{dL})$, there were similar proportion of patients who achieved withinrange serum phosphorus at 24 and 52 weeks in the SO (57.1 and 62.5\%) and sevelamer (60.7 and 64.3\%) arms. This was accomplished with $58 \%$ lower pill burden when using SO compared to sevelamer, which is comparable to the findings of our analysis.

In this analysis, we also used 2 novel metrics to account for the role of nutritional status in the manage- 
Table 3. Comparison of clinical parameters for patients with in-range phosphorus during SO follow-up

\begin{tabular}{|c|c|c|c|}
\hline \multicolumn{4}{|c|}{ Patients with serum phosphorus $\leq 5.5 \mathrm{mg} / \mathrm{dL}$ for $\geq 3$ months of SO follow-up ( $n=110)$} \\
\hline Serum phosphorus, $\mathrm{mg} / \mathrm{dL}$ & $5.81(0.08)$ & $4.97(0.07)$ & $<0.0001$ \\
\hline Albumin-corrected calcium, mg/dL & $9.43(0.06)$ & $9.36(0.06)$ & 0.08 \\
\hline Intact PTH, pg/mL & $406(33)$ & $425(32)$ & 0.4 \\
\hline Phosphorus-attuned albumin, $\times 10^{3}$ & $0.68(0.01)$ & $0.77(0.01)$ & $<0.0001$ \\
\hline Phosphorus-attuned nPCR, $\times 10^{3} \mathrm{dL} / \mathrm{kg} /$ day & $0.18(0.01)$ & $0.21(0.01)$ & $<0.001$ \\
\hline Serum creatinine, $\mathrm{mg} / \mathrm{dL}$ & $10.3(0.4)$ & $10.2(0.4)$ & 0.12 \\
\hline $\mathrm{K}_{\mathrm{ru}}, \mathrm{mL} / \mathrm{min} / 1.73 \mathrm{~m}^{2}$ & $3.58(0.38)$ & $3.25(0.34)$ & 0.3 \\
\hline $\mathrm{PD} \mathrm{Kt} / \mathrm{V}$ & $1.57(0.12)$ & $1.73(0.09)$ & 0.3 \\
\hline Total Kt/V & $2.2(0.1)$ & $2.3(0.1)$ & 0.3 \\
\hline Intact $\mathrm{PTH}, \mathrm{pg} / \mathrm{mL}$ & $430(32)$ & $391(30)$ & 0.087 \\
\hline Weight, kg & $85.9(2.7)$ & $87.1(2.7)$ & 0.007 \\
\hline Serum albumin, $\mathrm{g} / \mathrm{dL}$ & $3.71(0.04)$ & $3.63(0.04)$ & 0.001 \\
\hline Phosphorus-attuned albumin, $\times 10^{3}$ & $0.59(0.01)$ & $0.75(0.01)$ & $<0.0001$ \\
\hline Phosphorus-attuned nPCR, $\times 10^{3} \mathrm{dL} / \mathrm{kg} /$ day & $0.17(0.01)$ & $0.21(0.01)$ & $<0.0001$ \\
\hline Serum creatinine, $\mathrm{mg} / \mathrm{dL}$ & $11.7(0.5)$ & $11.3(0.5)$ & 0.002 \\
\hline $\mathrm{K}_{\mathrm{ru}}, \mathrm{mL} / \mathrm{min} / 1.73 \mathrm{~m}^{2}$ & $2.71(0.44)$ & $2.40(0.37)$ & 0.5 \\
\hline $\mathrm{PD} \mathrm{Kt} / \mathrm{V}$ & $1.59(0.17)$ & $1.80(0.13)$ & 0.3 \\
\hline Total Kt/V & $2.0(0.2)$ & $2.2(0.1)$ & 0.3 \\
\hline
\end{tabular}

Values are expressed as least-squared means (SE), $p$ values compare least-squared means between treatment periods.

* Pill burden at baseline was calculated only for patients who received PB prescriptions through FreseniusRx ( $n=68)$. Follow-up $\mathrm{PB}$ pill burden for patients with no baseline binder available through FreseniusRx $(n=42)$ was found to be 4.1 SO pills/day.

** Pill burden at baseline was calculated only for patients who received PB prescriptions through FreseniusRx $(n=29)$. Follow-up $\mathrm{PB}$ pill burden for patients with no baseline binder available through FreseniusRx $(n=34)$ was found to be $4.4 \mathrm{SO}$ pills/day.

$\mathrm{K}_{\mathrm{ru}}$, residual urea clearance; nPCR, normalized protein catabolic rate; PD, peritoneal dialysis; PTH, parathyroid hormone; SO, sucroferric oxyhydroxide; $\mathrm{PB}$, phosphate binder.

Table 4. Comparison of pill burden and serum phosphorus by $\mathrm{K}_{\mathrm{ru}}$ at baseline

\begin{tabular}{|c|c|c|c|c|c|c|c|c|c|}
\hline \multirow[t]{2}{*}{ Parameter } & \multicolumn{3}{|c|}{ No $\mathrm{K}_{\mathrm{ru}}$ recorded $(n=64)$} & \multicolumn{3}{|c|}{$\mathrm{K}_{\mathrm{ru}} \leq 3 \mathrm{~mL} / \mathrm{min} / 1.73 \mathrm{~m}^{2}(n=122)$} & \multicolumn{3}{|c|}{$\mathrm{K}_{\mathrm{ru}}>3 \mathrm{~mL} / \mathrm{min} / 1.73 \mathrm{~m}^{2}(n=72)$} \\
\hline & $\mathrm{BL}$ & SO & $p$ value & $\mathrm{BL}$ & $\mathrm{SO}$ & $p$ value & $\mathrm{BL}$ & SO & $p$ value \\
\hline $\mathrm{PB}$ pills/day* & $10.7(0.3)$ & $4.4(0.3)$ & $<0.0001$ & $10.6(0.3)$ & $4.4(0.3)$ & $<0.0001$ & $6.7(0.3)$ & $3.7(0.3)$ & $<0.0001$ \\
\hline Serum phosphorus, mg/dL & $6.57(0.16)$ & $6.21(0.15)$ & 0.001 & $6.96(0.14)$ & $6.52(0.13)$ & $<0.0001$ & $5.97(0.16)$ & $5.85(0.15)$ & 0.22 \\
\hline $\begin{array}{l}\text { Patients with serum } \\
\text { phosphorus } \leq 5.5 \mathrm{mg} / \mathrm{dL}\end{array}$ & $10 / 64(15.6)$ & $20 / 64(31.3)$ & 0.008 & $18 / 122(14.8)$ & $31 / 122(25.4)$ & 0.012 & $29 / 72(40.2)$ & $38 / 72(52.8)$ & 0.049 \\
\hline
\end{tabular}

Values are expressed as least-squared means (SE) for continuous variables, and $n / n(\%)$ for categorical variables.

$p$ values compare summary estimates between treatment periods.

* PB pill burden was calculated only for patients who received PB prescriptions through FreseniusRx.

$\mathrm{BL}$, baseline; SO, sucroferric oxyhydroxide follow-up; $\mathrm{K}_{\mathrm{ru}}$, residual urea clearance; $\mathrm{PB}$, phosphate binder. 
ment of phosphorus, that is, phosphorus-attuned albumin and nPCR, in that serum albumin and nPCR were each divided by serum phosphorus respectively. These 2 metrics are meant to address the concern that lowering serum phosphorus by restricting dietary protein intake (represented by nPCR) may cause more harm $[23,24]$, and that lower protein intake is associated with lower serum albumin in dialysis patients [25]. Indeed, both low nPCR and low serum albumin levels are associated with worse outcomes including higher mortality in dialysis patients. Hence, controlling serum phosphorus without restricting dietary protein intake or without lowering serum albumin is the preferred goal.

Patients with serum phosphorus $\leq 5.5 \mathrm{mg} / \mathrm{dL}$ during SO follow-up had a mean reduction in serum phosphorus from 5.81 to $4.97 \mathrm{mg} / \mathrm{dL}(p<0.0001)$ and a $54 \%$ reduction in $\mathrm{PB}$ pills/day. Significant improvements in phosphorusattuned albumin $\left(0.68 \times 10^{3}\right.$ to $\left.0.77 \times 10^{3}, p<0.0001\right)$ and phosphorus-attuned nPCR $\left(0.18 \times 10^{3}\right.$ to $0.21 \times 10^{3} \mathrm{dL} /$ $\mathrm{kg} /$ day, $p<0.001)$ were also observed. In patients who achieved in-range serum phosphorus during SO followup but had serum phosphorus levels $>5.5 \mathrm{mg} / \mathrm{dL}$ during baseline, a notable improvement in serum phosphorus (6.54 to $5.1 \mathrm{mg} / \mathrm{dL}, p<0.0001$ ) and iPTH (430 to $391 \mathrm{pg} /$ $\mathrm{mL}, p=0.09)$ were observed, along with a $53 \%$ reduction in PB pills/day (9.7 to 4.6, $p<0.0001$ ) Treatment with calcimimetics and active vitamin $\mathrm{D}$ for all patients and patients with in-range serum phosphorus is shown in online supplementary Tables S3, S4. Phosphorus-attuned albu$\min \left(0.59 \times 10^{3}\right.$ to $\left.0.7510^{3}, p<0.0001\right)$ and phosphorusattuned nPCR $\left(0.17 \times 10^{3}\right.$ to $0.21 \times 10^{3} \mathrm{dL} / \mathrm{kg} /$ day, $p<$ $0.0001)$ also increased from baseline. These changes may show the benefits of achieving in-range serum phosphorus levels.

Residual renal function is a contributor to phosphate clearance in PD patients [26]; thus, we stratified patients based on $\mathrm{K}_{\mathrm{ru}}$ at baseline. Patients with $\mathrm{K}_{\mathrm{ru}}>3$ had a higher percentage with in-range serum phosphorus levels at baseline and SO follow-up when compared to patients without baseline $\mathrm{K}_{\mathrm{ru}}$ measured or $\mathrm{K}_{\mathrm{ru}} \leq 3$. There was also a lower number of $\mathrm{PB}$ pills/day in the patients with $\mathrm{K}_{\mathrm{ru}}>3$ at both baseline (6.7) and SO follow-up (3.7) compared to baseline (10.7 and 10.6) and SO follow-up (4.4 and 4.4) for patients without recorded $\mathrm{K}_{\mathrm{ru}}$ and $\mathrm{K}_{\mathrm{ru}} \leq 3$, respectively.

$\mathrm{SO}$ is an iron-based $\mathrm{PB}$ thus anemia and iron indices were analyzed. The changes in ferritin and TSAT levels were consistent with those mentioned in prior reports of minimal iron absorption in phase III clinical trial results $[20,27]$. Patients not treated with IV iron during the phase III clinical trial showed small mean increase in serum ferritin $(+71.9)$ and TSAT $(+3.9 \%)$ between weeks 24 and 52 [27].

Limitations of our study include utilization of existing clinical records. Although the results may be more generalizable, possible errors or missing data from the clinical database are possible. Our analysis relies on pharmacy fills, which allows for good accuracy for timing and pills/day. However, follow-up ends when patient switches their pharmacy, even if medication is not discontinued. Reasons for patient being switched from their baseline $\mathrm{PB}$ to $\mathrm{SO}$ or discontinuing SO during follow-up are not available but may include non-adherence to filling prescriptions, adverse events, switch to another pharmacy, insurance coverage, and out of pocket costs. Although dietitians provide nutritional education to patients using approved educational materials, exact dietetic advice was not sufficiently recorded in the EHR. Reasons for discontinuation of baseline or follow-up PBs were not available. Also, there is no independent unexposed group available for comparison with the SO group, and so the SO group acts as their own comparator group during baseline.

\section{Conclusion}

In conclusion, the number of prescribed $\mathrm{PB}$ pills/day was reduced by half among adult $\mathrm{PD}$ patients treated with $\mathrm{SO}$, while the proportion of patients who achieved inrange serum phosphorus (serum phosphorus $\leq 5.5 \mathrm{mg}$ / $\mathrm{dL}$ ) increased.

\section{Disclosure Statement and Funding}

L.H.F., V.P., L.A., N.J.O., C.M., and R.J.K. are employees of Fresenius Medical Care, North America. C.M. and R.J.K. own stock in the company. R.J.K. is on the Board of Directors of Advanced Renal Technologies. D.W.C. is a consultant and speaker for Fresenius Medical Care. K.K.-Z. has received honoraria and/ or support from Abbott, Abbvie, Alexion, Amgen, ASN (American Society of Nephrology), Astra-Zeneca, Aveo, Chugai, DaVita, Fresenius, Genentech, Haymarket Media, Hofstra Medical School, IFKF (International Federation of Kidney Foundations), ISH (International Society of HD), International Society of Renal Nutrition \& Metabolism (ISRNM), JSDT (Japanese Society of Dialysis Therapy), Hospira, Kabi, Keryx, Novartis, OPKO, NIH (National Institutes of Health), NKF (National Kidney Foundations), Pfizer, Relypsa, Resverlogix, Sandoz, Sanofi, Shire, Vifor, UpToDate, ZS-Pharma. Fresenius Medical Care North America Renal Therapies Group provided funding for the study. 


\section{References}

1 Lukowsky LR, Mehrotra R, Kheifets L, Arah OA, Nissenson AR, Kalantar-Zadeh K: Comparing mortality of peritoneal and hemodialysis patients in the first 2 years of dialysis therapy: a marginal structural model analysis. Clin J Am Soc Nephrol 2013;8:619-628.

2 Klarenbach SW, Tonelli M, Chui B, Manns BJ: Economic evaluation of dialysis therapies. Nat Rev Nephrol 2014;10:644-652.

3 Coentrão LA, Araújo CS, Ribeiro CA, Dias CC, Pestana MJ: Cost analysis of hemodialysis and peritoneal dialysis access in incident dialysis patients. Perit Dial Int 2013;33:662670.

4 Rubin HR, Fink NE, Plantinga LC, Sadler JH, Kliger AS, Powe NR: Patient ratings of dialysis care with peritoneal dialysis vs hemodialysis. JAMA 2004;291:697-703.

5 United States Renal Data System: 2016 USRDS Annual Data Report: Epidemiology of Kidney Disease in the United States. Bethesda, MD, National Institutes of Health, National Institute of Diabetes and Digestive and Kidney Diseases, 2016.

6 Tonelli M, Pannu N, Manns B: Oral phosphate binders in patients with kidney failure. N Engl J Med 2010;362:1312-1324.

7 Cupisti A, Gallieni M, Rizzo MA, Caria S, Meola M, Bolasco P: Phosphate control in dialysis. Int J Nephrol Renovasc Dis 2013;6:193205.

8 Rroji M, Seferi S, Cafka M, Petrela E, Likaj E, Barbullushi M, Thereska N, Spasovski G: Is residual renal function and better phosphate control in peritoneal dialysis an answer for the lower prevalence of valve calcification compared to hemodialysis patients? Int Urol Nephrol 2014;46:175-182.

9 Cozzolino M, Stucchi A, Rizzo MA, Brenna I, Elli F, Ciceri P, Bover J, Cusi D, Gallieni M: Phosphate control in peritoneal dialysis. Contrib Nephrol 2012;178:116-123.

10 Galassi A, Cupisti A, Santoro A, Cozzolino M: Phosphate balance in ESRD: diet, dialysis and binders against the low evident masked pool. J Nephrol 2015;28:415-429.

11 Hutchison AJ: Oral phosphate binders. Kidney Int 2009;75:906-914.

12 Sprague SM: A comparative review of the efficacy and safety of established phosphate binders: calcium, sevelamer, and lanthanum carbonate. Curr Med Res Opin 2007;23:31673175 .

13 Gutekunst L: An update on phosphate binders: a dietitian's perspective. J Ren Nutr 2016; 26:209-218.

14 Wang S, Alfieri T, Ramakrishnan K, Braunhofer P, Newsome BA: Serum phosphorus levels and pill burden are inversely associated with adherence in patients on hemodialysis. Nephrol Dial Transplant 2014;29: 2092-2099.

15 Hung KY, Liao SC, Chen TH, Chao MC, Chen JB: Adherence to phosphate binder therapy is the primary determinant of hyperphosphatemia incidence in patients receiving peritoneal dialysis. Ther Apher Dial 2013;17: 72-77.

16 Parker K, Nikam M, Jayanti A, Mitra S: Medication burden in CKD-5D: impact of dialysis modality and setting. Clin Kidney J 2014;7: 557-561.

17 Covic A, Rastogi A: Hyperphosphatemia in patients with ESRD: assessing the current evidence linking outcomes with treatment adherence. BMC Neph 2013;14:153.

18 Chiu YW, Teitelbaum I, Misra M, de Leon EM, Adzize T, Mehrotra R: Pill burden, adherence, hyperphosphatemia, and quality of life in maintenance dialysis patients. Clin J Am Soc Nephrol 2009;4:1089-1096.

19 Coyne DW, Ficociello LH, Parameswaran V, Anderson L, Vemula S, Ofsthun NJ, Mullon C, Maddux FW, Kossmann RJ, Sprague SM: Real-world effectiveness of sucroferric oxyhydroxide in patients on chronic hemodialysis: a retrospective analysis of pharmacy data. Clin Nephrol 2017;88:59-67.
20 Floege J, Covic AC, Ketteler M, Mann J, Rastogi A, Spinowitz B, Rakov V, Lisk LJ, Sprague $S$ : One-year efficacy and safety of the ironbased phosphate binder sucroferric oxyhydroxide in patients on peritoneal dialysis. Nephrol Dial Transplant 2015;30:1037-1046.

21 Payne RB, Carver ME, Morgan DB: Interpretation of serum total calcium: effects of adjustment for albumin concentration on frequent frequency of abnormal values and on detection of change in the individual. JCP 1979;32:56-60.

22 US-DOPPS Practice Monitor, September 2017; http://www.dopps.org/dpm.

23 Lynch KE, Lynch R, Curhan GC, Brunelli SM: Prescribed dietary phosphate restriction and survival among hemodialysis patients. Clin J Am Soc Nephrol 2011;6:620-629.

24 Shinaberger CS, Greenland S, Kopple JD, Van Wyck D, Mehrotra R, Kovesdy CP, KalantarZadeh K: Is controlling phosphorus by decreasing dietary protein intake beneficial or harmful in persons with chronic kidney disease? Am J Clin Nutr 2008;88:1511-1518.

25 Eriguchi R, Obi Y, Streja E, Tortorici AR, Rhee CM, Soohoo M, Kim T, Kovesdy CP, Kalantar-Zadeh K: Longitudinal associations among renal urea clearance-corrected normalized protein catabolic rate, serum albumin, and mortality in patients on hemodialysis. Clin J Am Soc Nephrol 2017;12:11091117.

26 Evenepoel P, Meijers BK, Bammens B, Viaene L, Claes K, Sprangers B, Naesens M, Hoekstra T, Schlieper G, Vanderschueren D, Kuypers D: Phosphorus metabolism in peritoneal dialysis- and haemodialysis-treated patients. Nephrol Dial Transplant 2016;31: 1508-1514.

27 Covic AC, Floege J, Ketteler M, Sprague SM, Lisk L, Rakov V, Rastogi A: Iron-related parameters in dialysis patients treated with sucroferric oxyhydroxide. Nephrol Dial Transplant 2017;32:1330-1338. 